\title{
Errors And Competencies In Speaking Indonesian Language Students Of Diponegoro University, Semarang, Indonesia
}

\author{
Suharyo*, Muhammad Suryadi, Sri Puji Astuti, Patricia Ruth \\ Faculty of Humanities, Diponegoro University, Semarang 50275, Indonesia
}

\begin{abstract}
Error and competence in speaking Bahasa (Indonesian language) are always an interesting topic to discuss because language is dynamic. Mistakes that also reflect language competence can occur in all walks of life from the general public, students, to university students. This paper highlights the mistakes and at the same time, competence in speaking Indonesian language, among students of Diponegoro University. Data was extracted through a questionnaire distributed via MS Form. The results are (a) the average number of students $(80-90 \%)$ is competent in distinguishing standard and non-standard words, (b) Some students (60-85\%) are competent in distinguishing standard/complete form of words (in Predicate) in a sentence, (c) a small portion of students (14-32\%) is incompetent to distinguish it, (d) $60-85 \%$ of students are able to distinguish effective and ineffective sentences, (e) on average (50\%), students are able to distinguish correct sentences in terms of semantics, (f) most students ( $>90 \%$ ) agree: (1) Indonesian language must be maintained, taught and mastered; (2) Indonesian language is related to nationalism, personality and logic.
\end{abstract}

Keywords: errors, competency, language, university students

\section{Introduction}

Language competence and errors are always interesting topics to discuss because languages are always dynamic, following the developments and dynamics of the speakers, and Indonesian language is no exception. Indonesian language errors have been studied a lot, but there have never been any phenomena of language errors without errors, as explained by Supriani and Siregar [1]. There have been errors in the Indonesian language in the fields of words, sentences, paragraphs, spelling, and punctuation. According to their findings, mistakes can be mapped into three, namely elimination, addition, or wrong formation. Mistakes in Indonesian (spelling, letters, derivative words, pronouns $\mathrm{ku}^{-}{ }^{l}$, and prepositions) among students were also found by Hermawan [2]. The same mistake was raised by Leksono [3] for his research. He further stated four factors that cause errors, namely (1) lack of

\footnotetext{
*Corresponding author : haryo.sastra@gmail.com
} 
mastering the General Guidelines for Indonesian Spelling (PUEBI), (2) inaccuracy in writing, (3) lack of motivation to write, and (4) lack in mastering vocabulary. To overcome this, Leksono [3] suggested that learning to write is done by using process methods and efforts to improve understanding of language rules in students through reading and writing skills. The results of research by Nurwicaksono [4] mentioned that the error rate reached $89.08 \%$. Furthermore, he said that the use of italics reached $43.16 \%$; word writing error of $34.20 \%$; Related word errors and punctuation $16.04 \%$; and writing uptake element errors of $6.60 \%$. Meanwhile, Rumaniyar [5] found errors in diction and sentence fields in his research of mini research report students. That, according to Nina [6], is caused by two factors, namely internal factors (for example, sense of hearing, level of concentration, less attention, and mood) and external factors (unconducive classroom, unclear audio, seating position, rowdy class). Errors in the word field (conjunctions, question words, foreign terms) phrases and sentences (no subject matter, no predicate, and illogical sentences) were also reported in the results of his research. A similar thing was stated by Suharyo [9].

From previous studies, it can be seen that each research conducted on language errors at that time also found a number of language errors (Indonesian language) covering all aspects (letters, punctuation, spelling, words, sentences, paragraphs) and fields/levels (phonology, morphology, syntax, and discourse). This invites a fundamental question, why did this happen? Even though Indonesian language has been taught from elementary, junior high, senior high, even to university in a systemic, structured, and massive manner. The question is, is it because of the learning method, the teacher, or the attitude of learners who are being ignorant and trivializing Indonesian language? Or is it because Indonesian language does not have to be formally studied? Unfortunately, this paper is not intended to answer these questions. This paper only describes the language mistakes made by the students of Diponegoro University, Semarang, which at the same time means reflecting their competencies, as well as how students view Indonesian language as one of the cultural entities in the Indonesian speech community.

\section{Results and Discussion}

For the sake of this paper, students of Diponegoro University who were used as research samples were students of the Faculty of Social Science and Political Science, Faculty of Animal and Agriculture Sciences, and Faculty of Engineering as many as 235 students. Data was obtained through a questionnaire that was spread using the MS Form considering that it was in a Covid-19 pandemic situation. The results were analyzed by using presentation techniques for standard/correct/agreed and non-standard/incorrect/disagreeing answers and interpretation techniques for questions related to attitude.

Results. From the results of data analysis, it is obtained that (a) most students $(90 \%$ on average) can distinguish standard and non-standard words, (b) $60 \%-85 \%$ of students are competent in distinguishing morphologically standard/complete words (filling in the Predicate function ) in a sentence, and (c) a small portion (14\%-32\%) of students is not competent to distinguish; (d) $60 \%-85 \%$ of students are able to distinguish effective and ineffective sentences, (e) as much as $50 \%$ of students are competent in distinguishing correct sentences from the semantic side, (f) most students ( $>90 \%$ ) agree (1) Indonesian is maintained, taught, and must be mastered; and (2) according to them Indonesian language is related to nationalism, personality, and logic.

In addition to the above findings, in this paper it is worth mentioning that (1) some students $(57 \%)$ are unable to distinguish the standard word (the name of the Islamic holy book), namely the Al Quran, (2) $23.4 \%$ of students are not being able to distinguish the standard words of syakban and sya'ban, (3) there is a lack of consistency (although not too significant) 
answers to related questions which words are standard and not standard, especially occurs in the words of tekad and tekat ${ }^{2}$, miliar and milyar ${ }^{3}$, Al Quran and Al Qur'an, legalisir and legalisasi ${ }^{4}$; (4) there are still students (14-32\%) who have not been competent in distinguishing morphologically standard/complete words (as predicate fillers) in a sentence or even reaching $92.3 \%$ of students who do not know the standard word (memroses); (5) some students $(56.6 \%)$ have not been able to distinguish prepositional words $d i$ and $p a d a^{5}$ and their use in sentences, (6) 39.1\% students are also less competent in terms of word pun and juga $a^{6}$ in a sentence, (7) Likewise, as many as $(29.8 \%)$ were less able in terms of distinguishing the use of words sangat and sekali ${ }^{7}$, (b) $24.17 \%$ of students were less competent in distinguishing conjunctions (saling) and re-words (tukar-menukar) which meant saling; (8) as many as $31.1 \%$ students also lack competent understanding in terms of sentences that have multiple subjects.

From the semantic aspect, (1) $48.90 \%$ of students are less competent in distinguishing the words korban and kurban $^{8}$ in a sentence; (2) $84.3 \%$ of students are less competent in responding to differences in the use of the word kebijakan and kebijaksanaan ${ }^{9}$; (3) $49.4 \%$ of students are less competent in distinguishing the differences in the use of the word juara and pemenang ${ }^{10}$; and (4) $42.6 \%$ of students are incompetent in distinguishing the use of bekas and mantan $^{11}$ words in a sentence.

Regarding attitude, all students agree that Indonesian language needs to be taught and mastered. Students also agree with the statement that Bahasa (Indonesian language) is related to one's personality, culture, logic, and nationalism.

Discussion. With regard to results related to standard and nonstandard answers that reach above $90 \%$, there are two possibilities. First, students really are able to answer. Second, look for answers through sources. In addition, the things that can be noted are (1) there is a lack of consistency (although not too significant) answers of $1.7 \%$ related to tekad and tekat, (2) student competence in the field of morphology is quite good even though there are some students $(13.6 \%-32.3 \%)$ who are not yet competent and some even reach $92.3 \%$. From this finding, it can be seen that students are not yet competent in distinguishing consonant sounds and consonant clusters /sp/,/pr/; (3) there are still some students who are less competent in distinguishing the use of the word di and pada, pun and juga, korban and kurban, kebijakan and kebijaksanaan, bekas and mantan. 
Table 1. The Explanation of Indonesian Words

\begin{tabular}{|l|l|}
\hline \multicolumn{1}{|c|}{ Indonesian Word } & \multicolumn{1}{c|}{ Explanation } \\
\hline${ }^{1}$ ku & Indonesian pronoun for my \\
\hline${ }^{2}$ tekad/tekat & Indonesian words for determination \\
\hline${ }^{3}$ miliar/milyar & Indonesian words for billion \\
\hline${ }^{4}$ legalisir/legalisasi & Indonesian words for legalization \\
\hline${ }^{5}$ di/pada & Indonesian words for on \\
\hline${ }^{6}$ pun/juga & Indonesian words for also \\
\hline${ }^{7}$ sangat/sekali & Indonesian words for very \\
\hline${ }^{8}$ kurban/korban & Indonesian words for victim \\
\hline${ }^{9}$ kebijakan/kebijaksanaan & Indonesian words for policy \\
\hline${ }^{10}$ juara dan pemenang & Indonesian words for winner \\
\hline${ }^{11}$ bekas/mantan & Indonesian words for used \\
\hline${ }^{12}$ memproses/memroses & Indonesian words for processing \\
\hline
\end{tabular}

\section{Conclusions}

Things that can be recorded as conclusions. First, students of Diponegoro University are generally competent in distinguishing standard and non-standard words. Second, in general, students of Diponegoro University are competent in terms of using morphologically appropriate words in a sentence even though there are a number of other students that are less able to distinguish them. Third, some students of Diponegoro University are also quite competent in distinguishing effective and less effective sentences although there are also some students who are less competent. Fourth, the competency of students of Diponegoro University in terms of answering sentence questions viewed from the semantic aspect is also quite capable even though there are still those who have not been able to. Fifth, students are less competent in distinguishing the words of Al Qur'an and Al Quran, memproses and memroses $^{12}$. Sixth, syntactically students are less competent in distinguishing the use of words di and pada. Seventh, students are not capable in terms of differences in the use of the word kurban and korban. Eighth, scientifically, there are students who are less competent in understanding the differences in the use of words bekas and mantan, kebijakan and kebijaksanaan, juara and pemenang. Ninth, students argue that language is very closely related to culture and even to one's personality, so it is not surprising if there is a saying "bahasa menunjukkan bangsa" (language shows the nation). Even in Javanese culture there is a saying, "Wong Jawa ilang jawane, nek ora iso basa Jawa" (Javanese will lose their Javanese if they can't speak Javanese). 


\section{References}

1. Supriani, Reni dan Ida Rahmadani Siregar. "Penelitian Analisis Kesalahan Berbahasa" dalam Edukasi Kultural, p.67-76 (2016)

2. Hermawan, Agus. "Kesalahan Berbahasa dalam Makalah Mahasiswa Program Studi Pendidikan Bahasa IndonesiaTahun II Semester 3 Universitas Nahdatul Ulama Blitar" dalam Jurnal Pendidikan: Riset dan Konseptual, Vo;.3, No.1, p.35-38 (2019)

3. Leksono, M. Lukman. “Analisis Penggunaan PUEBI pada Tuga Makalah dan Laporan Praktikum Mahasiswa IT Purwokerto" dalam JP-BSI Jurnal Pendidikan Bahasa dan Sastra, Vol.4, No.2, p.116-120 (2019)

4. Nurwicaksono, Bayu Dwi, et.al. “Analisis Kesalahan Berbahasa Indonesia pada Teks Ilmiah Mahasiswa" dalam AKSIS Jurnal Pendidikan dan Sastra Indonesia Vol.2, No.2, p.138-153 (2018)

5. Rumaniyar, Eti. “Analisis Kesalahan Berbahasa Indonesia pada Penelitian Mini Mahasiswa" dalam Jurnal Edukasi, Vol.15, No.1, p.70-89 (2017)

6. Nina, Ahyati K.S. “Analisis Kesalahan Berbahasa pada Mata Kuliah Menyimak Mahasiswa PBSI Semester 1 Universitas Muhammadiyah Mataram” dalam Jurnal Ulul Albab, Vol.22, No.1 (2017)

7. Dinanti, Netty Fitria et.al. “Analisis Penggunaan Bahasa Indonesia pada Jurnal Ilmiah Pendidikan MIPA FKIP Bengkulu” dalam Jurnal Ilmiah Korpus, Vol.3, No.2 (2019)

8. Alber, Rhani Febria. "Analisis Kesalahan Tataran Sintakis dalam Kumpulan Makalah Mahasiswa Universitas Riau" dalam Geram (Gerakan AKtif Menulis), Vol.6, No.2 (2018)

9. Suharyo. "Kesalahan Berbahasa Mahasiswa Undip Studi Kasus Mahasiswa Fakultas Peternakan dan Pertanian" dalam NUSA, Vo.15, No,1, p.45-52 (2020) 